Research article

\title{
Host range, anatomy, biochemistry and impacts of Cuscuta reflexa Roxb.: A case study from the Betla National Park, Jharkhand, India
}

\author{
Preeti Kumari ${ }^{1}$, S. K. Tiwari ${ }^{2}$ and A. K. Choudhary ${ }^{1}$ \\ ${ }^{1}$ Department of Botany, Ranchi University, Ranchi-834002, Chhattisgarh, India \\ ${ }^{2}$ BRSM College of Agricultural Engineering and Technology, IGAU, Raipur, Chhattisgarh, India \\ *Corresponding Author: shashikant.au@gmail.com \\ [Accepted: 25 February 2017]
}

\begin{abstract}
The Cuscuta reflexa is a leaf less parasitic angiosperm belonging to the family Convolvulaceae and it is directly attaches to the host plants through the haustoria. During this investigation we find that the plant is a hemiand holoparasite, living on wood yielding, fruit yield in great medicinally important plants species. In present study, systematic survey and identification of the different host plants was undertaken. Surveys were conducted to find out the host plants of Cuscuta reflexa from different localities of Betla National Park areas of Jharkhand, India. In a survey 33 species, representing 30 genera belong to 23 families were recognized as host plants for it. Host plants were also examined for anatomical and biochemical studies. Haustorium penetration in host stem and size of the haustorium was found specific to the host. Each transverse section of host stem showed haustorium reached up to the secondary xylem. Poly-phenol oxidase activity and protein content were also studied in healthy and infected stem of Ziziphus mauritiana, Cajanus cajan and Ficus glomerata by Cuscuta reflexa. It was interesting to note that the protein content is markedly stimulated in all infected host plants. The maximum stimulation was recorded in Ziziphus mauritiana while minimum in Artocarpus integrifolia. The impact of Cuscuta reflexa on host growth, allometry and reproduction was also studied and found that it was major factor, which lead to changes in competitive balances between host and non-host species and therefore affect community structure, vegetation and population dynamics. Impacts on hosts may further affect herbivores, pollinators and seed vectors, and behaviour \& diversity of these is often closely linked to the presence and abundance of parasitic plants.

Keywords: Host plants - Parasite - Wood yielding trees - Anatomy - Poly-phenol oxidase - Protein.
\end{abstract}

[Cite as: Kumari P, Tiwari SK \& Choudhary AK (2017) Host range, anatomy, biochemistry and impacts of Cuscuta reflexa Roxb.: A case study from the Betla National Park, Jharkhand, India. Tropical Plant Research 4(1): 95-102]

\section{INTRODUCTION}

Cuscuta is an obligate angiosperm parasitic climber found commonly throughout India. It has about 100-170 species which attach various trees, shrubs, herbs and affect commercially valuable plants. We know that the plants water and other essential inorganic nutrients absorbed through conducting cells. The xylem connections between host and parasite, while organic substances transported from phloem tissue of host plants to parasite. Cuscuta ranges in severity based on its species and the species of host, the time of attach and whether any viruses are also present in the host plants (Kumar et al. 2012). Cuscuta is also known as Amerbel and it is used for various purposes viz. as a purgative, in the treatment of liver disorders, cough and itching, respiratory dieses and treatment of falling of hairs. It is known that it contains phenolics and flavonoids compound. Due to presence of such organic compounds it acts as Anti-inflammatory and anti-cancerous properties (Udavant et al. 2012). Fungi, nematodes, bacteria, and viruses are probably the first things that come to mind in the current list of parasites available in nature. Above parasite are responsible for development, growth and production of plants and crops i.e. it affects the economy of any country, but it may surprise to know that parasitic flowering 
plants are also important parasite. The purpose of this research work is to provide complete information about relationships of these fascinating and unusual plants and also to focus upon those that negatively affect the plant nutrients and production of crops. Most of the plants available in nature are autotrophs and produce their own carbon sources through photosynthesis. Although some plants such as Indian pipe (Monotropa) lack chlorophyll and appear to be parasitic, they are mycoheterotrophs (parasites of mycorrhizal fungi) and, hence, only indirectly parasitize the trees on which the mycorrhizal fungi are found. A haustorium is a modified root that forms a morphological and physiological link between the parasite and host (Kujit 1969). It is useful to make a distinction between the terms "parasite" and "pathogen." Parasite is from the Greek para (beside) and sitos (grain or food) which literally means "beside the food". If a plant also induces disease symptoms in a host, then it is a pathogen as well as parasite. A general term that refers to both parasites and mycotrophs that derive carbon from sources other than their own photosynthesis is heterotrophic, which simply means "different feeding."Cuscuta, dodder (Convolvulaceae-Morning Glory Family) The species of Cuscuta, is commonly known as dodder, and among the entire parasite it is the best known and common parasitic plants. The biology and control of dodders was reviewed in (Dawson et al. 1994). Dodders have a broad host range, although monocots are less preferred. The genus Cuscuta contains three subgenera. Members of the subgenus Monogyna are robust vines that may attack and kill fruit trees. Many researchers have been reported about cuscuta but no anybody has been studied and work carried out related to Cuscuta in BNP.

The present investigation is emphasizing on the host plants of Cuscuta reflexa Roxb. from different localities of Betla National Park areas of Jharkhand, India. Anatomy of Cuscuta and its host plants has been studied. We have also studied the biochemical attributes like enzyme poly-phenol oxidase and protein content from healthy and infected host plants, as well as impacts of Cuscuta reflexa has been also reported.

\section{MATERIALSAND METHODS}

Study Area

Betla National Park (BNP) is located in the District of Plamu situated between latitude $23^{\circ} 25$ and $23^{\circ} 55^{\prime}$ North and longitudes $83^{\circ} 50^{\prime}$ and $84^{\circ} 36^{\prime}$ East, in the state of Jharkhand, India. The total area of the project Tiger circle is $1306 \mathrm{~km}^{2}$. Out of above areas $979.97 \mathrm{~km}^{2}$ area of the PTR has been declared as plamu wildlife sanctuary and out of that an area of $226.32 \mathrm{~km}^{2}$ has been notified as a Betla National Park in 1996. It is located in the western part of Chhootanagpur and covered by Plamu, Garhwa and Lathehar District. It is also part of the Central India Landscape and extends into the Sanjay-Dubri Tiger reserve and Achanakmar-Kanha tiger landscape through the Jashpur and Mahan forest of Chhattisgarh. In this areas mainly dry mixed forest, dry sal forest, moist sal forest and moist mixed forest are presents. BNP is also becoming home to many unwanted nonnative plants.

\section{Data collection}

The diversified host species of Cuscut reflexa Roxb. were studied in Betla National Park of Jharkhand, India. Extensive field survey was undertaken during the year i.e. from 2015-2016 at different areas including forest villages and out skirts, higher plant parasites occurring on the host species. These are photographed and collected the host species and parasites for identification and confirmed with the help of existing literature.

The host plants of Cuscuta were collected from different localities of Betla National Park of Jharkhand, India and identified by using recent standard books and current literature. The hosts were categorized in herbs, shrubs, climbers, lianas, trees; angiosperms, gymnosperms, and their families; medicinal, insecticidal and economically important plants. The transverse sections of Cuscuta host stem have been taken from highly affected area. Then these sections have been stained with dilute safranin and dilute light green using double staining technique. And now these ready slides have observed by using light microscope to study the anatomical details in host stem and Cuscuta shoot association. The activity of an oxidative enzyme poly-phenol oxidase and protein content were studied from healthy and infected host plants of Cuscuta using the following methods.

\section{Poly-phenoloxidase analysis}

The Poly-phenol oxidase (PPO) activity has been analyzed as per the procedure of Mahadevan \& Sridhar (1982). The reaction mixture consisted $1.5 \mathrm{ml}$ of $0.1 \mathrm{M}$ Sodium phosphate buffer (pH 6.5) and $200 \mu \mathrm{l}$ of the enzyme extract. $0.01 \mathrm{ml}$ Catechol has added to the reaction mixture to start the reaction. Poly-phenol oxidase activity has expressed as change in absorbance at $412 \mathrm{~nm}$ per minute/g fresh weight of tissue. 
Protein analysis

Fresh steam sample $100 \mathrm{mg}$ has extracted in $0.1 \mathrm{M}$ Sodium phosphate buffer $\left(\mathrm{pH} \mathrm{7.0)}\right.$ at $0-4{ }^{\circ} \mathrm{C}$. The homogenate has centrifuged for 20 minutes at $12000 \mathrm{rpm}$. The protein content of the sample has been determined by the method of Lowry et al. (1951). Protein $(100 \mu \mathrm{g})$ from different tubes has taken and mixed with $10 \mu \mathrm{l}$ of sample buffer in eppendorf tube, boiled for $3-4$ minutes and incubated at $4^{\circ} \mathrm{C}$ for 30 minutes. The samples containing equal amount of protein have loaded into wells of $12 \%$ polyacrylamide gel. Electrophoresis has carried out at constant voltage of 75 volts for two hours. The gels have stained with $0.2 \%$ coomassie brilliant blue (R-250) solution and distained with acetic acid/water. The hierarchical cluster analysis has performed on gel documentation system using NTSYS-pc software and the dendrogram has prepared using average linkage between groups based on presence/absence of protein bands in different lanes of the gel.

\section{RESULTS AND DISCUSSION}

Study the host plant of Cuscuta reflexa

In the present investigation, surveys have made during 2015 to 2016 to locate the host plants of Cuscuta in the Plamu Tiger reserve areas of Betla National Park in Jharkhand, India. In a survey 33 species, representing 30 genera belong to 23 families have been recorded as a host plants of Cuscuta (Table 1). In above observed host plants some are herbs, shrubs, climbers and trees and it is agricultural, horticultural, medicinal, weeds and economically important plants. Their life span may be annual, biennial or ephemeral. The present results clearly indicate that, dodder ranges in severity based on the species of host. The very common plants viz. Ziziphus mauritiana, Cajanus cajan and Ficus glomerata have very favorable hosts of Cuscuta, (Fig. 1) and when other suitable hosts were nearby Cuscuta shoots, Cuscuta spread from host plant to host plant often forming a dense mat of intertwined stems. It grows on each and every type of plants. In shaded areas, twining and attachment were greatly reduced. Nikam et al. (2014) reported Vitex negundo and Duranta plumier plat is a most favorable host plant in Baramati area of Pune district of Maharashtra and Reddy et al. (1990) reported Vitex negundo Linn., hedge plant as a new host for Cuscuta reflexa in Bidar, Karnataka. According to Jayasinghe et al. (2004), Cuscuta is widely distributed inSri Lanka. They searched 161 host plant species including rice, belonging to 59 families and 139 genera. Patel et al. (2004) presented tabulated data of 48 host plants parasitized by Cuscuta species in North Gujarat, India. From the different experimental studies Schoolmaster (2005) concluded that, Impatiens capensis Meerb. (Balsaminaceae) was anecessary nurse host for the parasitic plant Cuscuta grovonii in Schultes in Southeastern Michigan wetlands. One very interesting thing was revealed by Kelly (1992) i.e. in greenhouse experiments $C$. europaea accept (coil) host of high nutritional status and grow away from (reject) hosts of poor quality.

Table 1. List of host plants of Cuscuta reflexa Roxb. collected from Betla National Park, Plamu Tiger reserve areas in Jharkhand.

\begin{tabular}{|c|c|c|c|c|}
\hline $\begin{array}{l}\text { S. } \\
\text { No. }\end{array}$ & $\begin{array}{l}\text { Botanical names of Cuscuta host } \\
\text { plants }\end{array}$ & $\begin{array}{l}\text { Vernacular names of } \\
\text { Cuscuta host plants }\end{array}$ & Family & Uses \\
\hline 1 & Carissa spinarum $\mathrm{L}$. & Karonda & Apocynaceae & Medicinal \\
\hline 2 & Eugenia heyneana Duthie & kathjamun & Myrtaceae & Medicinal \\
\hline 3 & Acacia catechu (L.f.) Willd. & khair & Mimosaceae & Formation of katha \\
\hline 4 & Acacia nilotica (L.) Delile & Babul / Kikar & Mimosaceae & Tanin product \\
\hline 5 & Achyranthes aspera $\mathrm{L}$. & chirchiri & Amaranthaceae & Medicinal \\
\hline 6 & Adhatoda zeylanica Medik & Adosa & Acanthaceae & Medicinal \\
\hline 7 & Artocarpus integrifolia L.f. & Jack fruit / Kathal & Moraceae & Vegetable \\
\hline 8 & Aegle marmelos (L.) Corrêa & Bel & Rutaceae & Fruit \\
\hline 9 & Syzygium cumini (L.) Skeels & Jammun & Myrtaceae & Fruit \\
\hline 10 & Aerva lanata $\mathrm{L}$. & Gorakhbuti & Amaranhaceae & Medicinal \\
\hline 11 & Spondias mangifera Wild. & Amra / Amda & Anacardiaceae & Pickle \\
\hline 12 & Ageratum conyzoides $\mathrm{L}$. & Jangli pudina & Asteraceae & Medicinal \\
\hline 13 & Ziziphus xylopyrus (Retz.) Willd. & kathber & Rhamnaceae & Medicinal \\
\hline 14 & Azadirachta indica A.Juss. & Neem & Meliaceae & Wood \\
\hline 15 & Bombax ceiba L. & semal & Bombacaceae & For cotton \\
\hline 16 & Butea monosperma (Lam.) Taub. & Palas & Fabaceae & Gum \\
\hline 17 & Albizia lebbeck (L.) Benth. & Sirish & Mimosaecae & Wood \\
\hline 18 & Emblica officinalis Gaertn. & Amla. & Euphorbiaceae & Medicinal \\
\hline 19 & Lawsonia inermis $\mathrm{L}$. & Mehendi, & Apiaceae & Dye \\
\hline
\end{tabular}


Kumari et al. (2017) 4(1): 95-102

\begin{tabular}{lllll}
\hline 20 & Moringa oleifera Lam. & Sahjan, & Moringaceae & Vegetable \\
21 & Tamarindus indica L. & Imali & Caesalpiniaceae & Medicine \\
22 & Terminalia bellirica (Gaertn.) Roxb. & Bahera & Combretaceae & Medicinal \\
23 & Terminalia chebula Retz. & Harra & Combretaceae & Medicinal \\
24 & Madhuca longifolia L. & Mahua & Sapotaceae & Medicinal drug \\
25 & Vitex negundo L. & Nirgundi & Verbenaceae & Medicinal \\
26 & Cajanus cajan (L.) Millsp. & Arhar & Fabaceae & Pulses \\
27 & Ziziphus mauritiana Lam. & Ber / plum & Rhamnaceae & Fruit \\
28 & Shorea robusta Gaertn. & Sal / Sakhua & Dipterocarpaceae & Wood \\
29 & Annona squamosa L. & Sitaphal & Annonaceae & Fruit \\
30 & Pyrus communis Decne. & Naspati & Rosaceae & Fruit \\
31 & Dalbergia sissoo Roxb. & Shisam & Fabaceae & Wood \\
32 & Nerium oleander L. & Kaner & Apocynaceae & Ornamental \\
33 & Ficus glomerata Roxb. & Gular & Moraceae & Medicinal \\
\hline
\end{tabular}
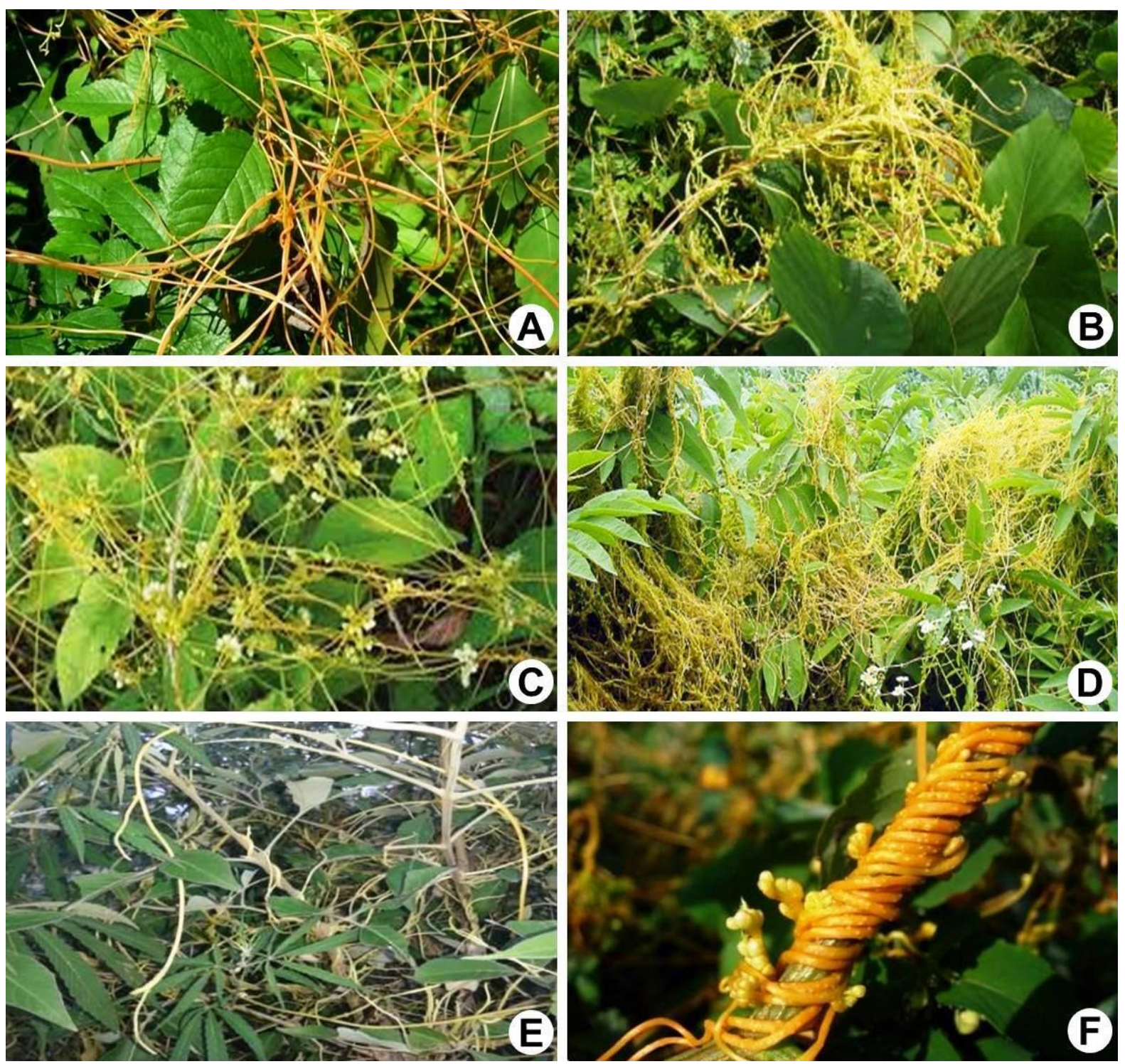

Figure 1. Plant affected by Cuscuta reflexa Roxb. in Betla National Park, Jharkhand: A-B, Ziziphus mauritiana Lam.; C-D, Cajanus cajan Lam. E-F, Ficus glomerata Roxb.

Anatomical study of host plant of Cuscuta reflexa

The light microscopic anatomical observations of Cuscuta reflexa Roxb and its host stem showed tremendous diversity (Fig. 2). The present result clearly indicates that, Cuscuta houstorium is easily penetrate in to the host plant steam and penetration depends on the size of both steam as well as Cuscuta. Each transverse section of host stem shows Cuscuta haustorium reached up to the secondary xylem. Here one of the interesting things has been observed that food material is available from phloem tissue instead of this Cuscuta inserted in to 
the next of phloem tissue of host plants. And this insertion shows only limited growth. The another common character was observed that the Cuscuta penetration has been affected the steam of cortex tissue and this tissue elongated towards the Cuscuta there for stem of host plants became completely changed its structure. In Cuscuta haustorium apical meristem and root caps are absent and its develops from cortical parenchyma cells of the pericycle. In addition, during the formation of the haustoria, it is also clear that cell elongation dominates over the cell division therefore the number of cells of the parasite endophytic system in the host is determined by the number of Cuscuta cortical parenchyma cells undergoing transformation. Furthermore, the haustoria have limited growth capacity. The anatomical studies of Cuscuta made by Ihl \& Wiese (2000). Haustoria formation was restricted to a sub apical region (area where the most intensive elongation of the steam) of $C$. reflexa stem. According to Arnaud et al. (1998) while the Cuscuta easily attached itself to its hosts, the first difficulty was to establish connection between xylem vessels and sieve-tubes. As per the studies of Dey \& KandPati (1998), transverse sections of the affected area of the stem of Digitaria ciliaris showed that the haustoria penetrate the host by rupturing the bulliform cells or epidermal pores.
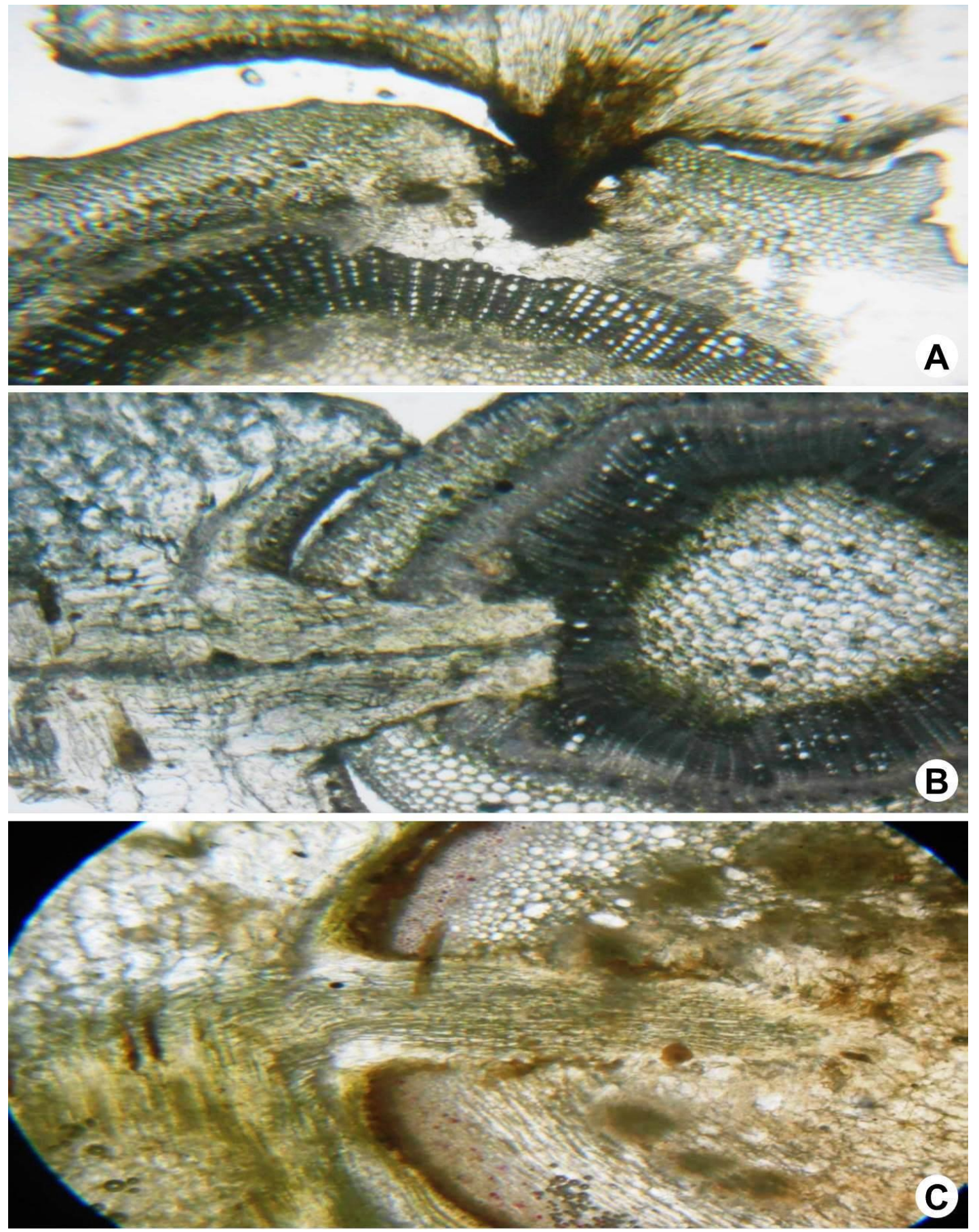

Figure 2. Anatomical structure of host plant stems infected by Cuscuta reflexa Roxb.: A, Ziziphus mauritiana Lam.; B, Cajanus cajan (L.) Millsp. C, Ficus glomerata Roxb. 
Study the Biochemistry of Cuscuta reflexa

Phenolic compounds are believed to impart resistance to disease in plants and poly-phenol oxidase (Catecholase and Cresolase) enzyme has been reported to be responsible for in vivo synthesis and accumulation of these compounds (Vaughan \& Duke 1984). In many cases, a close correlation has been found between the enhanced activity of poly-phenol oxidase andper-oxidase and the concentration of Phenolic substances on one hand and between plant resistances on the other (Dickinson \& JandLuca 1982). In the present investigation poly-phenol oxidase activity studied in healthy and infected stem of Ziziphus mauritiana, Cajanus cajan, Ficus glomerata, Emblica officinalis Gaerth and Artocarpus integrifolia (Table 2). The common trend of enzyme activity is stimulatory in infected host plants. None of the infected host shows decreasing trend of polyphenol oxidase activity. Present results clearly indicates the role of poly-phenol oxidase activity in plant diseases, so here it may concluded that increasing activity of poly-phenol oxidase enzyme markedly involve in physiological defense mechanism of host plants. The similar results are also proposed by many workers. The effect of polyphenol oxidase activity have been studied by Jite \& Tressa (1999) and found that an increase in poly-phenol oxidase activity in infected Jasminum plants with Uromyces hobsoni. Gawande et al. (2002) concluded that enzymes polyphenol oxidase and peroxidase are responsible for resistance or susceptibility of host plants against pathogen.

Table 2. Poly-phenol oxidase activity in healthy and infected host plant steam by Cuscuta reflexa Roxb. in Betla National Park areas.

\begin{tabular}{|c|c|c|c|}
\hline \multirow{2}{*}{$\begin{array}{l}\text { S. } \\
\text { No. }\end{array}$} & \multirow{2}{*}{ Plant material (Stem material) } & \multicolumn{2}{|c|}{ Poly-phenol oxidase activity $\left(\Delta\right.$ OD. $\mathrm{min}^{-1} \mathrm{~g}^{-1}$ fresh wt) } \\
\hline & & Healthy & Infected \\
\hline 1 & Ziziphus mauritiana Lam. & 5.20 & 12.78 \\
\hline 2 & Cajanus cajan (L.) Millsp. & 6.31 & 11.45 \\
\hline 3 & Ficus glomerata Roxb. & 5.63 & 9.12 \\
\hline 4 & Emblica officinalis Gaertn. & 6.63 & 7.78 \\
\hline 5 & Artocarpus integrifolia & 9.34 & 9.92 \\
\hline
\end{tabular}

Protein content studied in healthy and infected host plants steams of Ziziphus mauritiana, Cajanus cajan, Ficus glomerata, Emblica officinalis and Artocarpus integrifolia by Cuscuta reflexa has recorded in table 3 . It is interesting to note that the protein content is markedly stimulated in all infected host plants. The maximum stimulation occurs in Ziziphus mauritiana compared to another plants. Again increasing protein content proves its role in plants defense mechanism.

Table 3. Protein content in healthy and infected host plant steam by Cuscuta reflexa Roxb. in Betla National Park areas.

\begin{tabular}{llll} 
S. & \multirow{2}{*}{ Plant material (Stem material) } & \multicolumn{2}{c}{ Protein content $(\boldsymbol{\mu g}$ per 100 gm dry tissue) } \\
\cline { 3 - 4 } No. & & Healthy & Infected \\
\hline 1 & Ziziphus mauritiana Lam. & 60 & 190 \\
2 & Cajanus cajan (L.) Millsp. & 85 & 205 \\
3 & Ficus glomerata Roxb. & 72 & 139 \\
4 & Emblica officinalis Gaertn. & 68 & 120 \\
5 & Artocarpus integrifolia L.f. & 167 & 210 \\
\hline
\end{tabular}

Impact of Cuscuta reflexa (Dodder plant)

Cuscuta is a parasite and it affects different plans, agricultural crops such as Ziziphus mauritiana \& Cajanus cajan and also affects the horticultural crops. Others dodder ranges in severity based on its species and the species of the host, the time of attack. Parasitism has major impacts on host growth; allometry and reproduction. Cuscuta also affect the behaviours, pollinators, seed vectors and diversity of host plants.

Ecological and economic impact of dodder species

Cuscuta also affect the environment as well as ecological balance in the nature. It affect the economy of farmer because Cuscuta spread in to the field and affect the growth of agricultural crops therefore very low production of crops. Cuscuta also affect the soil quality of the field. It decreases the arable surface, results in quantitative and qualitative crop losses, represents a vector concerning the transmission of such diseases as viroses and microplasmoses to the host plant, and its impact on the biodiversity determines the degradation of the landscapes' decorative aspect.

Impacts of parasitic plants on the plant community

Over one season, for instance, a single Cuscuta plant may form thousands of connections with many host 
species and may cover an area greater than $100 \mathrm{~m}$ (Kelly 1990), resulting in considerable impacts on the plant community despite its being perhaps less than 5\% of vegetation biomass (Pennings \& Callaway 1996) .

\section{Impacts of the parasite on other tropic levels}

It has been found that not only plants are affected by Cuscuta many other organisms such as birds and insect herbivores, other parasites and mycorrhizal fungi can be affected, either directly or indirectly. Parasite also affects the trophic levels because it is part of our biodiversity. Monitoring Cuscuta species and their spreading tendencies, as well as their prevention and therapy generates positive and immediate economic and social effects, by means of creating an integrated protection system of cultures. Moreover, it might also determine a qualitative and quantitative increase of agricultural production, which benefits farmers on the short, medium and long run. Furthermore, they will be mirrored in the quantity and quality of fodders, animal health and welfare of farmers; since it is universally acknowledged that the decrease in risk of diseases, parasites and weeds within agricultural ecosystems would influence public health and environmental protection in a very positive way.

\section{Impacts of the parasite on the abiotic environment}

The abiotic environment is also affected by parasitic plants and most significant types of ecosystems affected by Cuscuta species are the pratologic ecosystems. However, there is a huge number of species which represent host plants for dodders; this fact affecting the biodiversity of ecosystems at a process level, as well as with regard to human society and animal health.

\section{CONCLUSION}

In present study systematic survey and identification of the host's plants has been conducted to find out the host plants of Cuscuta reflexa Roxb. from different localities of Betla National Park areas of Jharkhand in India. In a survey total 33 species, representing 30 genera belong to 23 families have been observed as host plants of Cuscuta and Ziziphus mauritiana, Cajanus cajan and Ficus glomerata are most favorable host of Cuscuta. Host plants have also examined for anatomical and biochemical studies. Cuscuta haustorium penetration in host stem and size of the haustorium is specific to host and Cuscuta species. Each transverse section of host stem clearly shows that Cuscuta haustorium has been reached up to the secondary xylem. But these haustoria insertion was not up to the pith and shows limited specific growth. The another common character has observed that, the Cuscuta haustorium penetration in the host stem has affected on the cortex tissue and this tissue shows markedly elongation towards the Cuscuta stem and host stem structure has completely changed. The common trend of enzyme activity is stimulatory in infected host plants. Here it may concluded that increasing activity of polyphenol oxidase enzyme markedly involve in physiological defense mechanism of host plants. Protein content is markedly stimulated in all infected host plants. The maximum stimulation occurs in Ziziphus mauritiana compared to another plants. Parasitism has major impacts on host growth, allometry and reproduction. Impacts on hosts may further affect herbivores, pollinators and seed vectors, and the behavior and diversity of these is often closely linked to the presence and abundance of parasitic plants.

\section{REFERENCES}

Arnaud MC, Thalouarn P \& Fer A (1998) Caractérisation des mécanismes impliqués dans la résistance de plantes cultivées à deux phanérogames parasites (Cuscuta reflexa etStriga hermonthica. Les Phanerogames Parasites 192(1): 101-119.

Dawson JH, Musselman LJ, Wolswinkel P \& band Dorr I (1994) Biology and control of cuscuta. Reviews of Weed Science 6: 265-317.

Dey D \& KandPati BR (1998) Record of parasitism of cuscuta reflexa Roxb. on digitaria cilliaris Pers. Journal of Economic and Taxonomic Botany 22(1): 235-236.

Dickinson C \& JandLucas JA (1982) Plant Pathology and Plant Pathogen, Edition II, Vol. 6. Black-well Scientific Publication.

Gawande VL, Patil JV, Naik RM \& Kale AA (2002) Plant biochemical defense against powdery mildew (Erysiphe polygoni DC) disease in mungbean (Vigna radiate (L.) Wilczek). Journal of Plant Biology 29(3): 337-341.

Ihl B \& Wiese K (2000) Studie an Cuscuta reflexa ROXB. VIII. Mechanische Haustorieninduktion an nichtwindenden Achsen des Parasiten. Flora Jena 195(1): 1-8. 
Jayasinghe C, Wijesundara DSA, Tennekoon KU \& Marambe B (2004) Cuscuta species in the lowlands of Sri Lanka, their host range and host parasite association. Tropical Agricultural Research 16: 223-241.

Jite PK \& Tressa J (1999) Biochemical changes in Jasminum grandiflorum infected by Uromyces hobsoni. Indian Phytopathology 52(1): 77-78.

Kelly CK (1990) Plant foraging: a marginal value model and coiling response in Cuscuta subinclusa. Ecology 71: 1916-1925.

Kelly CK (1992) Resource Choice in Cuscuta europaea. Proceedings of the National Academy of Sciences of the United States of America 89(24): 12194-12197.

Kujit J (1969) The Biology of parasitic Flowering plants. University of California press, Berkeley, CA, USA.

Kumar A, Rani S \& Niketa SS (2012) Review on plant molecular biology, phytophysiology, phytochemistry and ethonopharmacology of Cuscuta reflexa Roxb. A wonderful parasitic plant. International Research Journal of Pharmacy 3(7): 30-38.

Lowry OH, RosebroughN J, Farr AL \& Randall RJ (1951) Protein measurement with the folin phenol reagent. Journal of Biological Chemistry 193(1): 265-275.

Mahadevan A \& Sridhar R (1982) Methods in physiological plant pathology, $2^{\text {nd }}$ Edition. Sivakami publication, Indra Nagar, Madras.

Patel DM, Bhatt DC, Dodia SK \& Parmar RP (2004) Selection of host plants by Cuscuta L. species in semi-arid area of Visnagar, North Gujarat. Advances in Plant Sciences 17(2): 549-552.

Pennings SC \& Callaway RM (1996) Impact of a parasitic plant on the structure and dynamics of salt marsh vegetation. Ecology 77: 1410-1419.

Reddy PP, Nalini AS \& Prabhakar AS (1990) Vitex negundo Linn.:- A new host for Cuscuta reflexa Roxb. Current Research 19(4): 55-56.

Nikam SS, Pawar SB \& Kanade MB (2014) Study of Cuscuta reflexa Roxb. with reference to host diversity, anatomy and biochemistry. Central European Journal of Experimental Biology 3(2): 6-12.

Schoolmaster DR (2005) Impatiens capensis (Balsaminaceae) Meerb. is a necessary nurse host for the parasitic plant Cuscuta gronovii (Convolvulaceae) Willd in Southeastern Michigan wetlands. American Midland Naturalist 153(1): 33-40.

Udavant PB, Satyanarayana SV \& Upasani CD (2012) Preliminary screening of Cuscuta reflexa stems for Anti inflammatory and cytotoxic activity. Asian Pacific Journal of Tropical Biomedicine S1: 303-307.

Vaughan KC \& Duke SO (1984) Function of polyphenol oxidase in higher plants. Physiologia Plantarum 60: $106-112$. 